\title{
An Orthogonal Biocatalytic Approach for the Safe Generation and Use of HCN in a Multistep Continuous Preparation of Chiral O-Ace- tylcyanohydrins
}

\author{
Aischarya Brahma ${ }^{1, a, b}$ \\ Biagia Musio ${ }^{1, b}$ \\ Uliviya Ismayilovac \\ Nikzad Nikbin ${ }^{\text {b }}$ \\ Sonja B. Kamptmann ${ }^{2, b}$ \\ Petra Siegert ${ }^{c}$ \\ Günter E. Jerominc \\ Steven V. Ley*b \\ $1^{\text {st }}$ biotransformation $\quad 2^{\text {nd }}$ biotransformation chemical protection \\ Martina Pohla

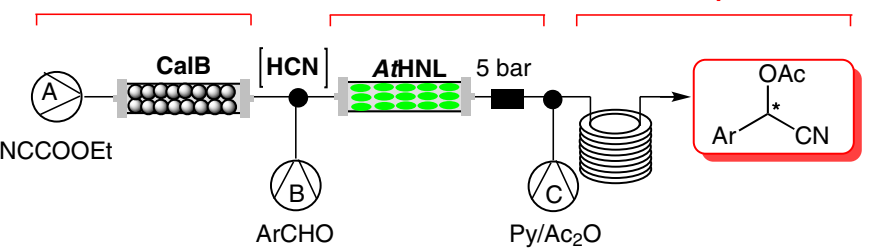 \\ a IBG-1: Biotechnology, Forschungszentrum Jülich, 52425 Jülich, Germany \\ ${ }^{b}$ Department of Chemistry, University of Cambridge, Cambridge, CB2 1EW, UK \\ svl1000@cam.ac.uk \\ c Institute of Nano- and Biotechnologies (INB), Aachen University of Applied Sciences, 52428 Jülich, Germany
}

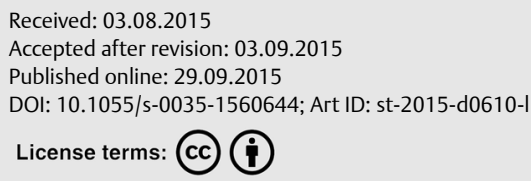

Abstract An enantioselective preparation of $O$-acetylcyanohydrins has been accomplished by a three-step telescoped continuous process. The modular components enabled an accurate control of two sequential biotransformations, safe handling of an in situ generated hazardous gas, and in-line stabilization of products. This method proved to be advantageous over the batch protocols in terms of reaction time ( 40 min vs 345 $\mathrm{min}$ ) and ease of operation, opening up access to reactions which have often been neglected due to safety concerns.

Key words Arabidopsis thaliana, novozyme 435, biocatalysis, flow, telescoped, HCN, cyanohydrins

Biocatalysis has been gaining in popularity over the past few years as a practical and more sustainable alternative to conventional synthetic methods, ${ }^{3}$ especially where chemo-, regio- and stereoselectivity are key issues. ${ }^{4}$ However, biocatalytic multistep approaches to chiral fine chemicals are still rare. ${ }^{5}$ This is partially due to the high demands of appropriate reaction parameters for different enzymes, which can be difficult to implement on scale. Recently, continuous processing technologies have been shown to be a powerful concept in order to tune reaction conditions in a very precise manner, ${ }^{6}$ enhance the sustainability and facilitate the scale-up of the chemical processes involving hazardous reagents. ${ }^{7}$ This becomes even more important during those multistep approaches, where the use of modular components for the downstream processing together with automated in-line analytics allow the control and coordination of all the stages of the processes. ${ }^{7 b, 8}$ In spite of these advantages, surprisingly few applications to multistep biocatalyt- ic strategies in flow ${ }^{9}$ have been reported so far in contrast to discrete single-step biotransformations. ${ }^{10}$ The application of hydroxynitrile lyases (HNLs) to access chiral cyanohydrins from aldehydes or ketones and HCN has a long tradition in bioorganic chemistry as well as for the production of respective intermediates for synthesis. ${ }^{11}$ Over the last few years, the $(R)$-selective hydroxynitrile lyase from Arabidopsis thaliana AtHNL has been characterized thoroughly with respect to its application for the preparation of chiral cyanohydrins. ${ }^{12}$ The crucial reaction parameters affecting its activity and enantioselectivity have been identified, with a special regard to the $\mathrm{pH}$, the temperature and the amount of water in the reaction medium. ${ }^{13}$ Despite the importance of the biocatalyzed hydrocyanation for the preparation of optically pure amino alcohols as chiral building blocks, ${ }^{14}$ this reaction still suffers from safety limitations related to the handling of the toxic and volatile hydrogen cyanide (HCN). ${ }^{15}$ Some HCN surrogates are under investigation, among which are trialkylsilyl cyanide, ${ }^{16}$ acetone cyanohydrin, ${ }^{17}$ diethyl cyanophosphonate, ${ }^{18}$ benzoyl cyanide, ${ }^{19}$ and acyl cyanide. ${ }^{20} \mathrm{~A}$ relatively cheap and less toxic cyanide source, ethyl cyanoformate (ECF), has enjoyed some successes in asymmetric cyanation of aldehydes, ketones, imines and olefins. ${ }^{21}$ To the best of our knowledge no biocatalyzed hydrolysis of ECF has been reported in literature so far. Thus, we decided to test the efficiency of different commercially available lipases for this transformation, and found that CalB immobilized on acrylic resin (Novozyme 435) in methyl tert-butyl ether (MTBE) showed the best efficiency for this transformation. ${ }^{22}$ A packed-bed reactor, PBR (microbore column $3 \mathrm{~mm} / 100 \mathrm{~mm}$ ), equipped with a back pressure regulator (5 bar), containing different amounts of CalB, was fed with a $1 \mathrm{M}$ solution of ECF in $\operatorname{MTBE}$ (Scheme 1). 


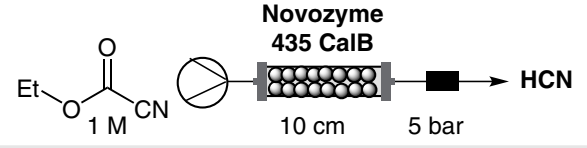

Scheme 1 Flow set-up of ECF hydrolysis

By adding a very small amount of ethanol or a potassium phosphate buffer solution (Kpi, pH 6.5) to the reaction medium, almost complete ECF hydrolysis (95-97\%) could be achieved with a residence time of 17.5 minutes (Table 1 , entries 4 and 5, see SI for details). Under these conditions the CalB-flow reactor was able to convert continuously 6.6 mmol of ECF in 120 minutes. Although a micro-aqueous system improved the ECF hydrolysis, it is noteworthy that in the absence of CalB only a small amount of ECF $(\leq 5 \%)$ was converted to $\mathrm{HCN}$.

Table 1 Optimization of the reaction parameters for the ECF hydrolysis in the flow set-up

\begin{tabular}{lccc}
\hline Entry & Flow rate $(\mathrm{mL} / \mathrm{min})$ & CalB $(\mathrm{mg})$ & Conv. $\left.^{(\%}\right)^{\mathrm{a}}$ \\
\hline 1 & 0.15 & 34 & $55^{\mathrm{b}}$ \\
2 & 0.05 & 34 & $56^{\mathrm{b}}$ \\
3 & 0.04 & 277 & $84^{\mathrm{c}}$ \\
4 & 0.04 & 277 & $95^{\mathrm{d}}$ \\
5 & 0.04 & 277 & $97^{\mathrm{e}}$ \\
\hline
\end{tabular}

a The conversion was calculated by GC analysis checking for the ECF depletion (see SI for details).

${ }^{b}$ A mixture of Novozyme 453 and celite was used to fill the reactor.

c Anhydrous MTBE was used.

${ }^{d}$ A mixture of MTBE/EtOH (3:1) was used.

e Micro-aqueous MTBE, prepared as described in SI, was used.

Pleasingly, impressive system stability was observed when a $1 \mathrm{M}$ solution of ECF in micro-aqueous MTBE was passed $(0.04 \mathrm{~mL} / \mathrm{min})$ through the CalB-reactor, showing only minor inactivation of the biocatalyst from $97 \%$ after one hour to $80 \%$ after eight hours of continuous operation (see SI for details).

When the same biotransformation was carried out in batch mode in a screw-cap equipped glass vial $(4 \mathrm{~mL})$ a reaction time of 120 minutes was necessary to hydrolyze 1 $\mathrm{mmol}$ of ECF quantitatively in the presence of $40 \mathrm{mg}$ of Novozyme 453 (Figure 1, a), and a modest lifetime was observed, with a $30 \%$ decrease in activity during the fourth cycle (Figure 1, b).

This new in situ generation of HCN opens up further opportunities to use this hazardous reagent for reactions which have often been neglected owing to safety reasons. Recently, the flow preparation of protected mandelonitrile derivatives by integrating an enzymatic step in aqueous media with a chemical reaction in an organic solvent was reported. ${ }^{23}$ However, the use of KCN as HCN source, lack of

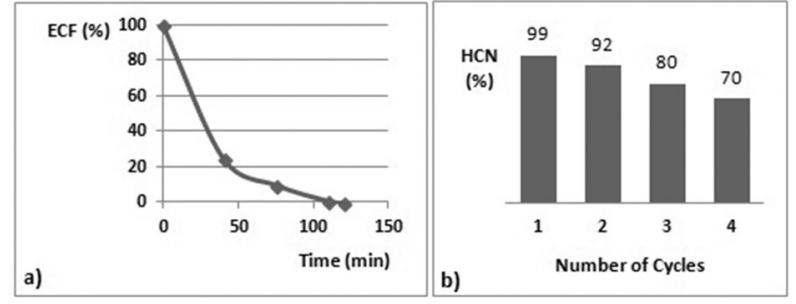

Figure 1 (a) CalB-catalyzed hydrolysis of ECF in a sample vial over time. Reaction conditions: a mixture of Novozyme 435 (40 mg) and ECF (1 $\mathrm{mmol}$ ) in $1 \mathrm{~mL}$ of micro-aqueous MTBE was stirred at room temperature (b) Study on the recyclability of a Novozyme 435-containing 'teabag' over four consecutive cycles (see SI for details).

biocatalyst recycling, and solvent switching were problematic, despite this being an attractive application of flow chemistry. With the aim of improving this approach, we decided to use the HCN-containing solution derived from the CalB-catalyzed reaction in a second AtHNL-catalyzed addition of HCN to aldehydes in a linked multistep flow process. Initial experiments were performed in a closed sample vial equipped with $25 \mathrm{mg}$ of AtHNL immobilized on celite (celite-AtHNL, $6.2 \mathrm{mg}$ of pure enzyme). A mixture of benzaldehyde $(0.5 \mathrm{M})$ and $\mathrm{HCN}$ solution $(1.5 \mathrm{M})$ in micro-aqueous MTBE was introduced into the vial and stirred at room temperature, affording after 125 minutes $(R)$-mandelonitrile with high conversion (99\%) and high ee (98\%; see SI for more details). Similar reaction conditions were applied in a flow system equipped with a packed bed reactor (microbore column $3 \mathrm{~mm} / 50 \mathrm{~mm}$ ) containing AtHNL immobilized on celite (Scheme 2 ).

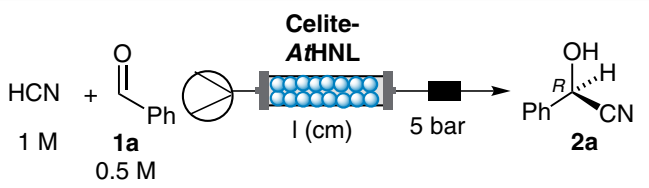

Scheme 2 Flow set-up of celite-AtHNL catalyzed synthesis of (R)-mandelonitrile

The effect of the residence time and the amount of the biocatalyst were considered, changing respectively the length of the reactor (1) and the amount of biocatalyst. When the residence time was increased a good $e e$ and a satisfactory conversion was observed (Table 2, entry 3 ). However, doubling the quantity of biocatalyst resulted in a beneficial effect, achieving good conversion and very high ee values (Table 2 , entry 4 ).

With these very promising data in hand, we attempted to develop a coupled process, assembling the two biotransformations consecutively in a continuous flow set-up. A solution of ECF ( $1 \mathrm{M}$ in micro-aqueous MTBE) was pumped $(0.04 \mathrm{~mL} / \mathrm{min})$ into a $10 \mathrm{~cm}$ PBR containing $277 \mathrm{mg}$ of CalB. The output of this first PBR, consisting of a $1 \mathrm{M}$ solution of 
Table 2 Optimization of the reaction parameters for the celite-AtHNLNovozyme 435 catalyzed synthesis of $(R)$-mandelonitrile in the flow set-up

\begin{tabular}{lccccc}
\hline Entry & $\mathrm{I}(\mathrm{cm})$ & $\begin{array}{c}\text { flow rate } \\
(\mathrm{mL} / \mathrm{min})\end{array}$ & Celite-AtHNL $(\mathrm{mg})$ & Conv. $^{\mathrm{a}}(\%)$ & ee (\%) \\
\hline 1 & 2.5 & 0.02 & $50^{\mathrm{b}}$ & 33 & 93 \\
2 & 2.5 & 0.04 & $50^{\mathrm{b}}$ & 20 & 93 \\
3 & 5.0 & 0.04 & $50^{\mathrm{c}}$ & 74 & 88 \\
4 & 5.0 & 0.04 & $100^{\mathrm{b}}$ & 85 & 96 \\
\hline
\end{tabular}

a Determined by ${ }^{1} \mathrm{H}$ NMR.

${ }^{b}$ Celite-AtHNL was used to fill the PBR.

' A mixture of celite-AtHNL $(50 \mathrm{mg})$ and pure celite $(50 \mathrm{mg})$ was used to fill the PBR.

$\mathrm{HCN}$, was mixed with a $0.5 \mathrm{M}$ solution of benzaldehyde in micro-aqueous MTBE $(0.04 \mathrm{~mL} / \mathrm{min})$ by means of a tee piece assembly. The resulting mixture was passed through a second reactor $(5 \mathrm{~cm})$, containing $100 \mathrm{mg}$ of celite-AtHNL and equipped with a back pressure regulator to keep the entire system pressurized at 5 bar (Scheme 3 ). As a proof of concept, $(R)$-mandelonitrile $2 \mathrm{a}$ was successfully obtained in very good conversion (97\%) and excellent ee (99\%).

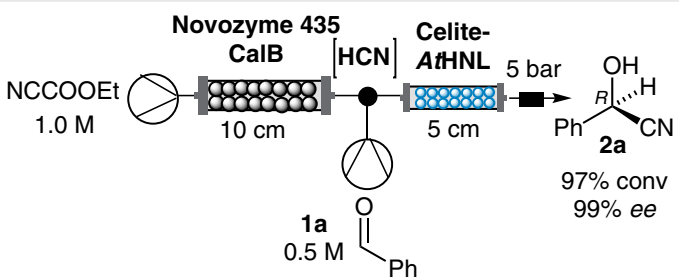

Scheme 3 Synthesis of $(R)$-mandelonitrile by a two-step biotransformation (Novozyme-celite-AtHNL)

Although this two-step biocatalytic approach showed persuasive advantages, the expensive and time-consuming purification of isolated enzymes could become an issue, especially during scale-up. The application of recombinant whole-cells as alternative biocatalyst appears more appealing in biotransformations, since no enzyme purification is needed, and, typically, the microorganisms present a high operational stability. ${ }^{24}$ The use of wild-type AtHNL-expressing E. coli BL21 (DE3) cells as whole-cell biocatalyst for the synthesis of chiral cyanohydrins has been investigated in detail by our group, demonstrating their efficiency and extreme stability in the same micro-aqueous reaction system as used in this study. ${ }^{12 \mathrm{~d}}$ We therefore studied AtHNLexpressing $E$. coli cells as biocatalyst in our two-step cascade synthesis of $(R)$-mandelonitrile, employing a PBR (10 $\mathrm{cm}$ ) containing $250 \mathrm{mg}$ of lyophilized cells (Scheme 4; see SI for details). According to this protocol, the desired $(R)$ mandelonitrile could be obtained in high conversion (99\%) and in very good ee (95\%).

Although this new biocatalytic tactic in flow is very promising, the well-known instability of cyanohydrins at neutral to alkaline $\mathrm{pH}$ and at room temperature needed to

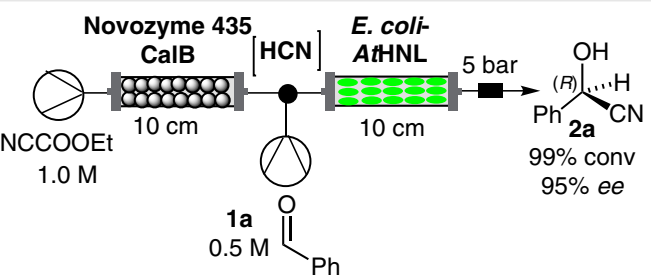

Scheme 4 Synthesis ( $R$ )-mandelonitrile by a two-step biotransformation (Novozyme 435-E. coli-AtHNL)

be addressed. The advantageous modularity of the flow system allowed us to perform an in-line protection of the newly formed cyanohydrins, as a three-step process. The new flow configuration consisted of two consecutive PBRs, containing Novozyme 435 and E. coli-AtHNL, respectively, a back-pressure regulator ( 5 bar) and a $2.0 \mathrm{~mL}$ PTFE coil for acetylation of the formed cyanohydrin (Scheme 5).
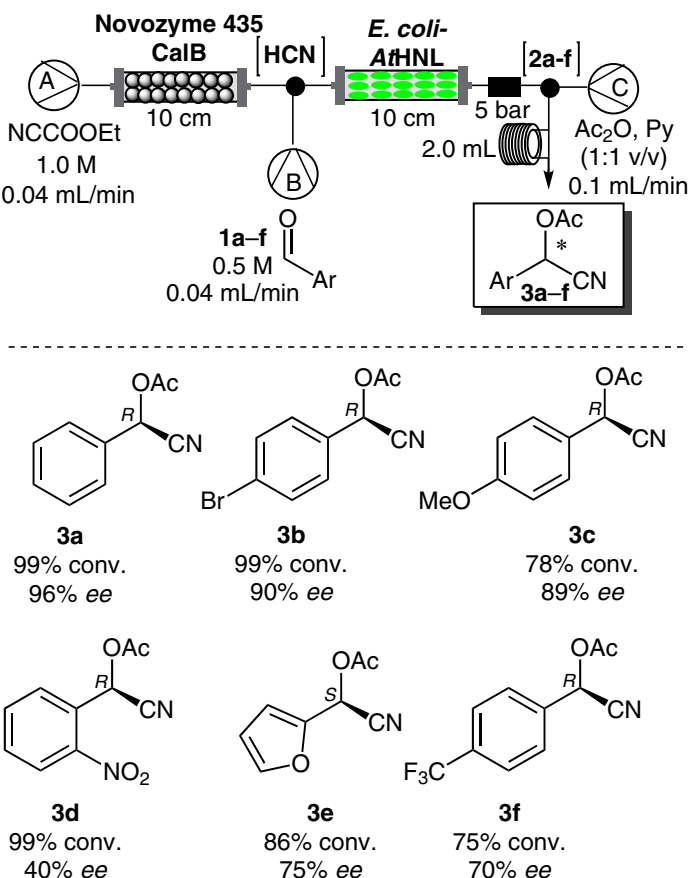

Scheme 5 Three-step chemo-biocatalytic cascade towards O-protected chiral cyanohydrins

This flow system was shown to be robust and applicable to a range of $\mathrm{O}$-acetylcyanohydrins, ${ }^{25}$ both electron-rich (3c) and electron-poor (3f), with high conversions over three steps (75-99\%, Scheme 5, conversion has been determined by ${ }^{1} \mathrm{H}$ NMR).

In conclusion, the advantages of the continuous flow technology have been explored with regard to a novel orthogonal biocatalytic approach. CalB and AtHNL were employed in a robust continuous telescoped process, involving an in situ HCN generation followed by addition to alde- 
hydes. High stereocontrol was observed in the subsequent hydrocyanation reaction. An in-line chemical acetylation enabled stabilization of newly formed cyanohydrins, giving access to a class of 0 -acetylcyanohydrins with very good conversions and ee values over three steps (75-99\% conversion; 40-98\% ee). The remarkable efficiency of whole recombinant cells as biocatalysts opens up further opportunities to more complex transformations, involving a combination of enzymes in flow reactor systems.

\section{Acknowledgement}

We gratefully acknowledge the Deutsche Forschungsgemeinschaft (DFG) within the research training group GRK 1166 'Biocatalysis in non-conventional media (BioNoCo)', and the EPSRC (Award Nos. $\mathrm{EP} / \mathrm{K} 009494 / 1$ and EP/K039520/1).

\section{Supporting Information}

Supporting information for this article is available online at http://dx.doi.org/10.1055/s-0035-1560644.

\section{References and Notes}

(1) These authors did the main part of the experiments and contributed equally. The manuscript was written through contributions of all authors. All authors have given approval to the final version of the manuscript.

(2) Present address: Novartis Pharma, AG WSJ-42.2.08, 4002 Basel, Switzerland.

(3) (a) Nestl, B. M.; Hammer, S. C.; Nebel, B. A.; Hauer, B. Angew. Chem. Int. Ed. 2014, 53, 3070. (b) Torrelo, G.; Hanefeld, U.; Hollmann, F. Catal. Lett. 2014, 145, 309.

(4) (a) Hollinshead, D. M.; Howell, S. C.; Ley, S. V.; Mahon, M.; Ratcliffe, N. M.; Worthington, P. A. J. Chem. Soc., Perkin Trans. 1 1983, 1579. (b) Multistep Enzyme Catalysis: Biotransformations and Chemoenzymatic Synthesis; Garcia-Junceda, E., Ed.; WileyVCH: Weinheim, 2008. (c) Pahari, P.; Kharel, M. K.; Shepherd, M. D.; van Lanen, S. G.; Rohr, J. Angew. Chem. Int. Ed. 2012, 51, 1216. (d) Wagner, N.; Bosshart, A.; Failmezger, J.; Bechtold, M.; Panke, S. Angew. Chem. Int. Ed. 2015, 54, 4182. (e) Heidlindemann, M.; Hammel, M.; Scheffler, U.; Mahrwald, R.; Hummel, W.; Berkessel, A.; Gröger, H. J. Org. Chem. 2015, 80, 3387.

(5) (a) Köhler, V.; Wilson, Y. M.; Dürrenberger, M.; Ghislieri, D.; Churakova, E.; Quinto, T.; Knörr, L.; Häussinger, D.; Hollmann, F.; Turner, N. J.; Ward, T. R. Nat. Chem. 2013, 5, 93. (b) Parmeggiani, F.; Lovelock, S. L.; Weise, N. J.; Ahmed, S. T.; Turner, N. J. Angew. Chem. Int. Ed. 2015, 54, 4608.

(6) (a) Baxendale, I. R.; Brocken, L.; Mallia, C. J. Green Process. Synth. 2013, 2, 211. (b) McQuade, D. T.; Seeberger, P. H. J. Org. Chem. 2013, 78, 6384 .

(7) (a) Alonso, N.; Muñoz, J. D. M.; Egle, B.; Vrijdag, J. L.; de Borggraeve, W. M.; de la Hoz, A.; Díaz-Ortiz, A.; Alcázar, J. J. Flow Chem. 2014, 4, 105. (b) Müller, S. T. R.; Wirth, T. ChemSusChem 2015, 8, 245. (c) Gasparini, G.; Archer, I.; Jones, E.; Ashe, R. Org. Process Res. Dev. 2012, 16, 1013. (d) Gutmann, B.; Cantillo, D.; Kappe, C. O. Angew. Chem. Int. Ed. 2015, 54, 6688.
(8) (a) Pastre, J. C.; Browne, D. L.; Ley, S. V. Chem. Soc. Rev. 2013, 42, 8849. (b) Newton, S.; Carter, C. F.; Pearson, C. M.; Alves, L. C.; Lange, H.; Thansandote, P.; Ley, S. V. Angew. Chem. Int. Ed. 2014, 53, 4915. (c) Webb, D.; Jamison, T. F. Chem. Sci. 2010, 1, 675. (d) Pellegatti, L.; Sedelmeier, J. Org. Process Res. Dev. 2015, 19, 551. (e) Ingham, R. J.; Battilocchio, C.; Fitzpatrick, D. E.; Sliwinski, E.; Hawkins, J. M.; Ley, S. V. Angew. Chem. Int. Ed. 2015, 54, 144. (f) Ghislieri, D.; Gilmore, K.; Seeberger, P. H. Angew. Chem. Int. Ed. 2015, 54, 678. (g) Sans, V.; Porwol, L.; Dragone, V.; Cronin, L. Chem. Sci. 2015, 6, 1258. (h) Maurya, R. A.; Min, K.-I.; Kim, D.-P. Green Chem. 2014, 16, 116.

(9) (a) Babich, L.; Hartog, A. F.; Van Hemert, L. J. C.; Rutjes, F. P. J. T.; Wever, R. ChemSusChem 2012, 5, 2348. (b) Yuryev, R.; Strompen, S.; Liese, A. Beilstein J. Org. Chem. 2011, 7, 1449. (c) Itabaiana, I.; Leal, I. C. R.; Miranda, L. S. M.; Souza, R. O. M. A. J. Flow Chem. 2013, 3, 122.

(10) (a) Jones, E.; McClean, K.; Housden, S.; Gasparini, G.; Archer, I. Chem. Eng. Res. Des. 2012, 90, 726. (b) Le Joubioux, F.; Bridiau, N.; Sanekli, M.; Graber, M.; Maugard, T. J. Mol. Catal. B: Enzym. 2014, 109, 143. (c) Baxendale, I. R.; Ernst, M.; Krahnert, W.-R.; Ley, S. V. Synlett 2002, 1641. (d) Baxendale, I. R.; Griffiths-Jones, C. M.; Ley, S. V.; Tranmer, G. K. Synlett 2006, 427. (e) Andrade, L. H.; Kroutil, W.; Jamison, T. F. Org. Lett. 2014, 16, 6092. (f) Tomaszewski, B.; Lloyd, R. C.; Warr, A. J.; Buehler, K.; Schmid, A. ChemCatChem 2014, 6, 2567.

(11) (a) Schmidt, M.; Griengl, H. Top. Curr. Chem. 1999, 200, 193. (b) Griengl, H.; Schwab, H.; Fechter, M. Trends Biotechnol. 2000, 18, 252. (c) Holt, J.; Hanefeld, U. Curr. Org. Synth. 2009, 6, 15. (d) Dadashipour, M.; Asano, Y. ACS Catal. 2011, 1, 1121.

(12) (a) Andexer, J.; von Langermann, J.; Mell, A.; Bocola, M.; Kragl, U.; Eggert, T.; Pohl, M. Angew. Chem. Int. Ed. 2007, 46, 8679. (b) Andexer, J. N.; Staunig, N.; Eggert, T.; Kratky, C.; Pohl, M.; Gruber, K. ChemBioChem 2012, 13, 1932. (c) Okrob, D.; Paravidino, M.; Orru, R. V. A.; Wiechert, W.; Hanefeld, U.; Pohl, M. Adv. Synth. Catal. 2011, 353, 2399. (d) Scholz, K. E.; Okrob, D.; Kopka, B.; Grünberger, A.; Pohl, M.; Jaeger, K. E.; Krauss, U. Appl. Environ. Microbiol. 2012, 78, 5025. (e) Kopka, B.; Diener, M.; Wirtz, A.; Pohl, M.; Jaeger, K.-E.; Krauss, U. Biotechnol. J. 2015, $10,811$.

(13) (a) Bauer, M.; Geyer, R.; Boy, M.; Griengl, H.; Steiner, W. J. Mol. Catal. B: Enzym. 1998, 5, 343. (b) Costes, D.; Wehtje, E.; Adlercreutz, P. Enzyme Microb. Technol. 1999, 25, 384. (c) Andexer, J. N.; von Langermann, J.; Kragl, U.; Pohl, M. Trends Biotechnol. 2009, 27, 599.

(14) North, M. Tetrahedron: Asymmetry 2003, 14, 147.

(15) Pritchard, J. D. HPA Compendium of Chemical Hazards: Hydrogen Cyanide; 2011, 1-31.

(16) Denmark, S. E.; Chan, W.J. Org. Chem. 2006, 71, 4002.

(17) Park, E. J.; Lee, S.; Chang, S. J. Org. Chem. 2010, 75, 2760.

(18) Abiko, Y.; Yamagiwa, N.; Sugita, M.; Tian, J.; Matsunaga, S.; Shibasaki, M. Synlett 2004, 2434.

(19) Watahiki, T.; Ohba, S.; Oriyama, T. Org. Lett. 2003, 5, 2679.

(20) Belokon, Y. N.; Gutnov, A. V.; Moskalenko, M.; Yashkina, L. V.; Lesovoy, D. E.; Ikonnikov, N. S.; Larichev, V. S.; North, M. Chem. Commun. 2002, 244.

(21) (a) Wang, J.; Li, W.; Liu, Y.; Chu, Y.; Lin, L.; Liu, X.; Feng, X. Org. Lett. 2010, 12, 1280; and references 6 and 7 within. (b) Purkarthofer, T.; Skranc, W.; Weber, H.; Griengl, H.; Wubbolts, M.; Scholz, G.; Pöchlauer, P. Tetrahedron 2004, 60, 735.

(22) Ismayilova, U. Bachelor Thesis; Aachen University of Applied Sciences: Germany, 2014. 
(23) Delville, M. M. E.; Koch, K.; van Hest, J. C. M.; Rutjes, F. P. J. T. Org. Biomol. Chem. 2015, 13, 1634.

(24) Tufvesson, P.; Lima-Ramos, J.; Nordblad, M.; Woodley, J. M. Org. Process Res. Dev. 2011, 15, 266.

(25) General procedure for the three-step cascade synthesis of chiral 0 -acetylcyanohydrins in flow: A $1 \mathrm{M}$ solution of ECF in microaqueous MTBE was pumped $(0.04 \mathrm{~mL} / \mathrm{min})$ into a $10 \mathrm{~cm}$ packed-bed reactor containing CalB $(277 \mathrm{mg})$. This first output, consisting of $1 \mathrm{M}$ solution of $\mathrm{HCN}$, was mixed with a $0.5 \mathrm{M}$ solution of aldehyde 1a-f in micro-aqueous MTBE $\left(0.04 \mathrm{~mL} / \mathrm{min}^{-1}\right)$ by means of a tee piece assembly. The resulting mixture was passed through a second bioreactor (Kinesis, Benchmark microbore column $3 \mathrm{~mm} / 100 \mathrm{~mm} 2 \times \mathrm{F}$ ), containing lyophilized E. coli-AtHNL- (250 mg), prepared as described in the SI (section S5). A back pressure regulator (5 Bar) was introduced after the packed bed reactor. The out coming solution was mixed with a mixture of pyridine/acetic anhydride (1:1) pumped by a compact HPLC pump (Knauer) and the resulting solution was passed through a PTFE coil $(2 \mathrm{~mL})$. The layers were collected and a sample $\left(50 \mu \mathrm{L}\right.$ in $500 \mu \mathrm{L}$ of $\left.\mathrm{CDCl}_{3}\right)$ was analyzed by NMR to check the formation of $(R)-\mathbf{3 a},(R)-\mathbf{3 b},(R)-\mathbf{3} \mathbf{c},(R)-\mathbf{3 d},(S)-\mathbf{3 e}$ and $(R)-3 f(75-99 \%)$. The optical purity of the products (40-98\%) was assessed by GC analysis. CAUTION: special precautions must be taken because the HCN is highly toxic. All work was carried in a well ventilated fumehood and a gas monitor for $\mathrm{HCN}$ was used during all the stages of the experiments. The excess of HCN (1 eq) was treated with an aqueous solution of sodium hypochlorite (10-15\%) until neutralization.

The spectroscopic data of compounds $\mathbf{3 a}-\mathbf{f}$ are in accordance with literature: (a) For 3a, see: Kadam, S. T.; Kim, S. S. Tetrahedron 2009, 65, 6330. (b) For 3b, see: Khan, N. U. H.; Agrawal, S.; Kureshy, R. I.; Abdi, S. H. R.; Mayani, V. J.; Jasra, R. V.J. Mol. Catal. A: Chem. 2007, 264, 140. (c) For 3c, see: Okrob, D.; Paravidino, M.; Orru, R. V. a.; Wiechert, W.; Hanefeld, U.; Pohl, M. Adv. Synth. Catal. 2011, 353, 2399. (d) For 3e, see: Sakai, T.; Wang, K.; Ema, T. Tetrahedron 2008, 64, 2178. (e) For 3f, see: Candiano, G.; Bruschi, M.; Musante, L.; Santucci, L.; Ghiggeri, G. M.; Carnemolla, B.; Orecchia, P.; Zardi, L.; Righetti, P. G. Electrophoresis 2004, 25, 1327

(R)-2-0-Acetyl-2-(2-nitrophenyl)acetonitrile (3d): ${ }^{1} \mathrm{H}$ NMR $\left(400 \mathrm{MHz}, \mathrm{CDCl}_{3}\right) \delta 2.21(\mathrm{~s}, 3 \mathrm{H}), 7.09(\mathrm{~s}, 1 \mathrm{H}), 7.68(\mathrm{dt}, J=8.2$, $1.4 \mathrm{~Hz}, 1 \mathrm{H}), 7.80(\mathrm{dt}, J=7.7,1.3 \mathrm{~Hz}, 1 \mathrm{H}), 7.93(\mathrm{dd}, J=7.8,1.2 \mathrm{~Hz}$, $1 \mathrm{H}), 8.20$ (dd, $J=8.2,1.2 \mathrm{~Hz}, 1 \mathrm{H}$ ). ${ }^{13} \mathrm{C}$ NMR $\left(150 \mathrm{MHz}, \mathrm{CDCl}_{3}\right.$ ): $\delta 20.1,59.6,115.0,125.8,129.3,131.3,134.5,147.0,168.3$. IR (Neat): 3123, 3036, 2333, 1756, 1399, 1116, $1064 \mathrm{~cm}^{-1}$. HRMS: $\mathrm{m} / z[\mathrm{M}+\mathrm{H}]^{+}$calcd for $\mathrm{C}_{10} \mathrm{H}_{9} \mathrm{O}_{4} \mathrm{~N}_{2}: 221.0557$; found: 221.0547 . 